\title{
Are We Not Being Entrepreneurial? Exploring the Home/Work Negotiation of South Asian Immigrant Women Entrepreneurs in Canada
}

\author{
Srabani Maitra
}

On a warm Sunday afternoon, I walk towards a buzzing neighbourhood in Toronto to meet Rehana, one of my research participants, who runs a small, informal sewing business from home within her own ethnic community. An ex-school teacher who immigrated to Canada with her husband from Pakistan in 2005, Rehana and her husband now live in Toronto with their two sons. They live in a predominantly Pakistani neighbourhood, in the Thorncliff area of Toronto. Rehana's husband Hamid is a former bank officer who now works full-time in a drug store as an assistant manager. He earns a little more than the minimum pay on an hourly basis. As I enter her building and walk towards the elevator, a typed red flyer on the notice board catches my attention: "Newly arrived salwar kameez ${ }^{1}$ and dress materials from Pakistan at an affordable price. Stitching and fitting also done. Contact Rehana at ...”. Rehana, along with other women whom I interviewed at various periods during my field work, run small businesses like that of sewing, catering or babysitting from home, almost always in those areas of Toronto with a high concentration of South Asians. Their businesses are specifically geared to function within their own communities. For example, women running garment businesses mainly sell salwar kameez, sari ${ }^{2}$ and other dress materials either stitched by them in Canada or brought over from their home countries. Many of them also do sewing, embroidery, crochet work, or stitch baby clothes, trousers, skirts, dresses and household items like curtains, pillow covers and cushion covers. For those involved in catering, most of the food items exclusively relate to South Asian cuisines, although a number of women also advertise their skills in preparing "western" dishes like various kinds of sandwiches, pies, pastries, etc. They usually cater for small functions and family events within their own communities.

\footnotetext{
1 Dress commonly worn by South Asian women.

2 Traditional dress in India and Bangladesh, also worn by women in Pakistan and Sri Lanka.

(C) SRABANI MAITRA, 2022 | DOI:10.1163/9789004499614_021
}

This is an open access chapter distributed under the terms of the CC BY-NC-ND 4.o license. 
It is necessary to clarify here that the appellation South Asian does not constitute a homogeneous group but differs in terms of religion, language, diet, cultural habits, caste or class status, as well as national identities. In North America, the diversity of people collectively described as South Asian includes those coming from India, Bangladesh, Pakistan, Sri Lanka, Nepal and Bhutan. Highly educated with university degrees and professional experience, these women immigrants, whom I had a chance to interact with, came to Canada along with their spouses in expectation of an improved quality of life and socio-economic opportunities. ${ }^{3}$ However, given the gendered and racialized nature of the labour market that exists in Canada, ${ }^{4}$ none of the women could get into a job that was commensurate with their previous educational or professional backgrounds. Home-based entrepreneurship was often a last resort to economically survive in Canada after multiple failures to enter into the mainstream labour market.

The focus on home-based work in Canada is vital for two reasons. First, since the 1990s, women's work in Canada has undergone increased "informalization" as well as "domestication" due to the trade liberalization and economic recessions characterizing the global world. ${ }^{5}$ While "informalization" refers to non-regulated work, both paid and unpaid, ${ }^{6}$ "domestication" has ushered in a "shift in the locations and sites of paid work from formal workplaces to domestic premises". ${ }^{7}$ According to Statistics Canada, while the number of employees working from home increased from 1.4 million in 2000 to 1.7 million in 2008, the number of self-employed increased more substantially. Their participation rate climbed from 54 per cent in 2006 to 60 per cent in 2008 , for a total of 1.8 million workers. ${ }^{8}$ This is in a context where, while 15 per cent of all workers in Canada are self-employed, they still account for about half of those who work from home. ${ }^{9}$ Statistics Canada further points out that the percentage of self-employed women working from home is higher than that of men (67 per

3 Statistics Canada, Women in Canada: A Gender-based Statistical Report (Ottawa, 2015).

4 Tania. Das Gupta et al, Race and Racialization: Essential Readings, second edn (Toronto, 2018); Jeffrey G. Reitz, "Tapping immigrants' skills: New directions for Canadian immigration policy in the knowledge economy", Choices, 11 (2005), pp. 1-18.

5 Annie Delaney et al., Homeworking Women: A Gender Justice Perspective (London, 2019); Wenona Giles and Valery Preston, "The Domestication of Women's Work: A Comparison of Chinese and Portuguese Immigrant Women Homeworkers", Studies in Political Economy, $5^{1}$ (1996), pp. 147-81.

6 Giles and Preston, "The Domestication of Women's Work", p. 147.

7 Ibid.

8 Statistics Canada, Working from Home: An Update (Ottawa, 2016).

9 Ibid. 
cent and 56 per cent, respectively) because of the various family responsibilities and child care that women have to engage in. ${ }^{10}$ While it is evident from the above that there can be a variety of home-based work ranging from paid work to businesses that are often gendered, what is still lacking in the analysis is a focus on how the creation of such work arrangements has disproportionately affected not just women but especially immigrant women of colour, who are over-represented in the informal, low-paid, precarious types of home work. ${ }^{11}$

Second, home work challenges any boundary existing between the private and the public by making it malleable. By dint of being located at home, the space ideologically constructed as "women's place", home work "brings wage into the place where 'love', 'duty', and 'need' ... compel labour". ${ }^{2}$ Within the limited literature that exists on immigrant women's home-based work in Canada, most studies concentrate on the gendered division of labour and the invisibility that home-based work shares with domestic work. ${ }^{13}$ In this context, scholars mainly argue that home-based work exacerbates women's dual responsibilities of household work and child care. Moreover, as the separation between home and work becomes quite blurry, home-based work often loses its "professional legitimacy not only at the macro level in the hierarchy of professions but also in the perception of other family members". ${ }^{14}$ Such underestimation is exacerbated when home work is undertaken by immigrant women of colour, who are often assumed to be docile and domesticated..$^{15}$ Consequently, despite earning at home, the social organization of the women's lives remains rooted in gender/race hierarchies and an ideology of motherhood. ${ }^{16}$

While the literature discussed above is important in identifying how racial and gendered processes affect women's (self) employment trajectories within homes, I argue that by depicting immigrant women of colour as merely a cheap labour force, these studies significantly undermine any resourcefulness

10 Martin Turcotte, Working at home: An update (Ottawa, 2010).

11 Giles and Preston, "The Domestication of Women's Work", p. 151.

12 Elisabeth Prügl and Eileen Boris, "Introduction", in Eileen Boris and Elisabeth. Prügl (eds), Home workers in global perspective: Invisible no more (New York and London, 1996), pp. 318 , p. 7 .

13 Alice Rangel de Paiva Abreu and Bila. Sorj, "Good Housewives: Seamstresses in the Brazilian Garment Industry", in Eileen Boris and Elisabeth Prügl (eds), Home workers in Global Perspective, pp. 93-110, pp. 101-07; Jinghzou Liu, "The Precarious Nature of Work in the Context of Canadian Immigration: An Intersectional Analysis", Canadian Ethnic Studies, 51 (2019), pp. 169-85.

14 Abreu and Sorj, "Good Housewives", p. 101; Delaney et al., Homeworking Women.

15 Lalaie Ameeriar, "Pedagogies of Affect: Docility and Deference in the Making of Immigrant Women Subjects", Signs:Journal of Women in Culture and Society, 40 (2015), pp. 467-86. Abreu and Sorj, "Good Housewives", pp. 101-02; Delaney et al., Homeworking Women. 
or initiatives that these women might articulate while coping with the various exclusionary practices they experience in the host country where they have migrated with skills, education and credentials. ${ }^{17}$ Only a few studies address women's negotiations and struggles while engaged in home-based work. ${ }^{18}$ Despite pointing out the disadvantages that immigrant women-especially immigrant women of colour-experience, these studies underscore the importance of understanding the strategic bargaining that women often engage in, thereby challenging those arguments that primarily describe women within home enterprises as a subservient and unpaid labour force.

Drawing on the above lines of argumentation, this paper, based on qualitative interviews with twenty-five South Asian home-based women entrepreneurs in Canada, examines the various exclusionary experiences of "living in a gender/race stratified society that force South Asian immigrant women to enter home-based work after migration and how they weather their diminished status from being full-time professionals in their home countries to part-time, low-income precarious business owners". ${ }^{19}$ In a country and society where gendered racism is deeply embedded, and Eurocentric ideals, values and norms dominate, South Asian women experienced difficulty in finding their bearings. The constraints were particularly evident when they tried to enter the labour market. Various institutionalized barriers such as the need for Canadian work experience, coupled with the discriminatory attitude of employers, systematically devalued and deskilled their previous education, knowledge or expertise, and pushed them to unemployment and eventual poverty. Marginalized and excluded from the labour market, these women found themselves facing a dilemma. On the one hand, there was the neoliberal thrust to remain

17 Srabani Maitra, "Points of Entry: Examining the Conditions of South Asian Immigrant Women's Entry into Enclave Entrepreneurship in Toronto", South Asian Diaspora, 5 (2013), pp. 123-37.

18 Arlene Dallalfar, "Iranian Women as Immigrant Entrepreneurs", Gender and Society, 8 (1994), pp. 541-61; Maitra, "Points of Entry"; Srabani Maitra, "Perspectives on Work and Family Lives: Exploring the Lived Experiences of South Asian Immigrant Mothers Working from Home in Toronto", in J. Sangha and T. Gonsalves (eds), South Asian Mothering: Negotiating Culture, Family and Selfhood (Toronto, 2013), pp. 149-64; Edwina Pio, "Ethnic Minority Migrant Women Entrepreneurs and the Imperial Imprimatur", Women in Management Review, 22 (2007), pp. 631-49; Margaret Walton-Roberts and Daniel Hiebert, "Immigration, Entrepreneurship, and the Family: Indo-Canadian Enterprise in the Construction Industry of Greater Vancouver", Canadian Journal of Regional Science, 20 (1997), pp. 119-40; Margaret Walton-Roberts and Geraldine Pratt, "Mobile Modernities: A South Asian Family Negotiates Immigration, Gender and Class in Canada", Gender Place and Culture, 12 (2005), pp. 173-95.

Maitra, "Points of Entry", p. 126. 
productive, self-sufficient and responsible citizen-subjects; on the other hand, there was the inability to enter their own professional fields, despite having the skills and education to be successfully employed in the Canadian labour market. These social realities constituted the everyday experiences of these women, and it is critical to address these issues when analysing their participation in home-based entrepreneurship. At the same time, it is also important to emphasize how women, despite being forced into low-end businesses at home, try different avenues to remain productive. Going

beyond notions of profit or economic competitiveness, such productivity entailed broader considerations about love, creativity and passion in their work. They actively refashioned their positions within their households, extending their love and support for the family members and also mobilizing ties with other women within the community, thereby challenging their stereotypical depiction as a silent, invisible, and extractable labour force. ${ }^{20}$

This paper therefore makes an important contribution to the literature on home-based work by highlighting how, far from the self-absorbed, profitoriented neoliberal enterprising self, these women, by evoking kin networks and by valuing their family lives and relationships, presented new forms of agential worker-subjects who actively negotiated various exploitative ideologies and barriers "for their own ends in the daily struggles". ${ }^{21}$ By providing new significance and meaning to their relationships with their families and with other women in the community, these home-based women workers also challenged the stereotypical assumptions of oppressed and isolated women reeling under family pressure within home-based economies. Negotiating their presence on the peripheries of the Canadian market economy that offered nothing more than precariousness, these women demonstrated how alternative crafting of an "enterprising self" was possible by "offering collaborative, meaningful work and relationships". ${ }^{22}$

20 Ibid.

21 Ngai Pun, Women Factory Workers in a Global Workspace (Durham and London, 2005), p. 61.

22 Tara J. Fenwick, “Transgressive Desires: New Enterprising Selves in the New Capitalism”, Work, Employment and Society, 16 (2002), pp. 703-23, p. 717. 


\section{Being Enterprising}

In Canada's neoliberal economy, where individuals are expected to choose their own path to economic growth and pursue "self-defined goals", ${ }^{23}$ starting a business as an entrepreneur is seen as an important initiative by immigrants for "penetrating" a totally foreign country, in which, often, economic choices and opportunities for them are severely constrained by the dominant groups of the host country. ${ }^{24}$ The idyllic portrayal of the neoliberal "enterprising self" can perhaps be best examined in the context of immigrant entrepreneurship, which is often promoted as a form of work that entails empowerment and agency for individuals willing to be flexible, risk-taking and determined to achieve success and professional development. Indeed, the emerging image of an entrepreneur is that of a self-made individual (read: white, middle-class man), daring and decided, driven by a sense of power and independence, characterized by such words as innovation, risk-taking, opportunity recognition and economic growth. ${ }^{25}$ These values associated with entrepreneurship are in sync with the "dominant western enterprise development models emphasizing competitive edge in a globalized market to attract investors and secure wealth". ${ }^{26}$ Within this context, the agency of the individual is defined in terms of an empowered and autonomous individual who can successfully establish the business against all odds. Closely tied to the neoliberal ideals of "pulling oneself up by one's bootstrap" and a "can do attitude", entrepreneurship thus evokes an image of empowerment where women and men are seen as developing their capabilities to improve their sense of individuality and confidence. Concurrently, this empowerment is seen as leading to the autonomy and agency that they can exercise to live a better life and subsequently assimilate into the mainstream community. ${ }^{27}$ Entrepreneurship then seems to portray a

23 Naila Kabeer, Reversed Realities: Gender Hierarchies in Development Thought (London and New York, 1994), p. 14.

24 Feiwel Kupferberg, "The Established and the Newcomers: What Makes Immigrant and Women Entrepreneurs so Special?", International Review of Sociology, 13 (2003), pp. 89-104.

25 Monica Boyd, "Family and Personal Networks in International Migration: Recent Developments and New Agendas", International Migration Review, 23 (1989), pp. 638-70.

26 Fenwick, “Transgressive Desires", p. 718.

27 Robert L. Bach, Jennifer B. Bach and Timothy Triplett, "The Flotilla Entrants: Latest and most controversial", Cuban Studies, 11 (1981), pp. 29-48; Alejandro Portes, "Modes of Structural Incorporation and Present Theories of Immigration", in Mary M. Kritz, Charles B. Keely and Silvano M. Tomasi (eds), Global Trends in Migration (New York, 1981), pp. 27997; Alejandro Portes and Robert L. Bach, "Immigrant Earnings: Cuban and Mexican Immigrants in the United States", International Migration Review, 14 (1980), pp. 315-41; 
classic example of neoliberal enterprising citizens who, amidst labour market insecurity and barriers, can create their own success through ingenuity, hard work and zeal. Those unable to do so, the "unenterprising" ones, tend to end up in the precariousness of the secondary labour market.

While entrepreneurship is usually depicted as a panacea for immigrants, especially unemployment or underemployment among immigrants of colour, South Asian women's home-operated businesses present a different dynamic. Being excluded from the white collar job market, they not only for the first time utilized the skills "they have learned in carrying out their domestic, maternal and family responsibilities" for economic purposes, ${ }^{28}$ but also reconfigured the home space, traditionally held as a space of leisure, freedom and privacy ${ }^{29}$ and ideologically held as distinct from the work space or that of the public sphere. ${ }^{30}$ Moreover, their businesses were small, low-income, with no benefits, and in most cases unaccounted for. These kinds of businesses are technically defined as own-account or solo self-employment - that is, where there are no paid employees ${ }^{31}$ — and are considered to be in an even more precarious position than self-employed employers. ${ }^{32}$

In the following sections, I will discuss the ways in which South Asian women negotiate neoliberal ideologies associated with economic productivity and success. First, despite being engaged in a precarious form of work, they demonstrate their love and passion for their work, challenging the notion of an abstract, highly individualized and competitive entrepreneur. Second, by cultivating ethnic ties with other community members, they foster collaborative relationships and reinvigorate "relational values".33

Alejandro Portes and Robert L. Bach, "The Latin Journey: Cuban and Mexican Immigrants in the United States" (Berkeley, CA, 1985).

28 Dallalfar, "Iranian Women as Immigrant Entrepreneurs", p. 549.

29 Graham Crow and Graham Allan, "Constructing the Domestic Sphere: The Emergence of the Modern Home in Post-war Britain", in H. Corr and L. Jamieson (eds), Politics of Everyday Life: Continuity and Change in Work and the Family (Basingstoke, 1990), pp. 1136; Jon Dart, "Home-based Work and Leisure Spaces: Settee or Work-Station?", Leisure Studies, 25 (2006), pp. 313-28.

$30 \quad$ Dart, "Home-based Work and Leisure Spaces"; Prügl and Boris, "Introduction".

31 Cynthia L. Cranford, Leah F Vosko and Nancy Zukewich "The gender of precarious employment in Canada", Relations Industrielles/Industrial Relations, 58:3 (2003), pp. 454-82.

32 ibid.

33 Fenwick, "Transgressive Desires". 
Exploring the complexities of the Canadian labour market

The whole application process took us ... one year ... I think ... and then we had to wait for four years after submitting the application, when we finally heard from the consulate. I remember we had to put in details of our education, work experience, language tests to get the required number of points to become eligible. Although I was the principal applicant, me and also my husband had to put all our qualification details. We went and got our educational certificates, letters from our past employers ... my god ... the amount of documents and information that we had to put in was huge. But we were determined to come here, we wanted a good life. So when we finally got accepted we were so happy.

The above quotation is from one my interviewees, Leena, who came to Canada in 2002 with her husband. A former kindergarten teacher in India, Leena, during the interview, shared with me the documentation that is involved in the application process for Canadian immigration. According to her, the process was not merely handing in a bunch of papers, but involved matching their qualifications with the $\mathrm{NOC}^{34}$ list, putting in the details of their work experience, education, and then waiting for four long years before they finally heard about their application. Education, work experience and language skills are some of the important determinants for getting selected for Canadian immigration, and the amount of documentation that Leena and her husband had to hand in makes clear the rigorous and time-consuming selection process that exists for choosing some of the "best and brightest" immigrants considered suitable for settling down in Canada.

Canada has an active immigration programme that invites individuals to apply to enter the country and contribute her/his skills, education and experience to the social, cultural and economic growth of Canada's national life. Immigrants are thus considered "assets" to this nation and only those who are held to be substantially qualified to enter Canada are inducted into the migration process. ${ }^{35}$ The selection of "qualified" immigrants is based on criteria

34 The National Occupational Classification (NOC) is a "nationally accepted reference on occupations in Canada", available at HRSDC, www5.hrsdc.gc.ca, last accessed 2 June 2021, to understand the jobs available in Canada's labour market and to find out their eligibility to those job requirements.

35 Daniel Hiebert, "Economic Associations of Immigrant Self-Employment in Canada", International Journal of Entrepreneurial Behaviour and Research, 8 (2002), pp. 93-112. 
like education, work experience, age, English/French language proficiency, arranged employment in Canada and adaptability, so that only those are chosen who can enrich Canada not only demographically but also economically by contributing to its labour market and maintaining its status as a globally competitive knowledge economy. No wonder, the other interviewees also had to experience rigorous screening like Leena in terms of their application for immigration. Despite not being the principal applicants in most cases, ${ }^{36}$ the participants (including those sponsored by their husbands) still had to submit their educational and work-related certificates as these were vital for successful acceptance of their applications.

During the interviews, most of the respondents also expressed how happy and excited they were to be in what they felt was a "land of opportunity". Repeatedly, the women reiterated how they thought of immigration as an opportunity to enhance their career, earn copiously, and ensure a secure future for themselves and their children. Neeta, who had worked in a nongovernmental organization (NGO) in Bangladesh before coming to Canada in 2004, described how the very thought of migrating to Canada brought happiness not only to her but also to her whole family: "Coming to Canada was the dream come true. We were all very happy including my family back in Bangladesh. For the entire family it was like a dream come true".

Neeta had planned to work in a community organization or NGO after migration as she was confident that her five years of experience working with women's issues in Bangladesh would be useful in getting her the desired job. Many other women also mentioned such reasons as "better opportunities", "better future" and "good life" as dominant reasons for migration. Overall, a majority of the women expressed their happiness at being able to come to Canada. As Shazia, a computer data entry operator from Pakistan explained, "We had a very high expectation about Canada. I was very happy that I was coming to abroad, you know people back home think a lot about foreign life".

Thus an enmeshment of desires and expectations pervaded the initial stage of women's migration to Canada, and their decision to look for a job also came out of such a desire to be settled in the labour market as soon as possible. Although the majority of the women were not principal applicants, being highly educated and having worked before, they were very keen on entering the labour market as quickly as possible.

36 Amongst the women interviewed only Saadiya, Neeta and Leena applied as principal applicants while in the rest of the cases the women were co-applicants. Their spouses were the principal applicants. 
The keenness of these women to work after immigration corresponds to the research findings of scholars such as Das Gupta and Jamal, ${ }^{37}$ who indicate a strong tendency on the part of most South Asian immigrant women to work. Prompted by eagerness to develop their careers as well as contribute to the fast-depleting reserve money, the respondents in my study also wanted to start earning as early as possible. Their fervour to find gainful employment was also driven by the zeal to be self-sufficient and earning members of the Canadian society. Laxmi had been working in an administrative position in Sri Lanka and did not want to depend on her husband after immigration. Similarly Sabitha, who had been working as a teller in a bank in India, did not want to remain without work: "After settling down in Toronto, my first intention was to find a job. I have worked for so many years and never had to depend on anyone for money. I wanted to support myself here too". A common theme that seemed to emerge from our conversations was the confidence these women had regarding their qualifications. While their desire to migrate to Canada may have been induced by global capitalism and Canada's proactive immigration system, as far as their abilities were concerned, none of the interviewees looked upon themselves as deficient or lacking in any way, such that their prospects of becoming successful members of mainstream Canadian society and its economy might be hindered.

Perhaps the interviewees' first introduction to the notion that their past experience and education might be perceived as inadequate or deficient by the Canadian system was when they started applying for jobs and going out to meet job counsellors and recruiters. They would then start wondering why they were not getting any response from the employers or the recruiters, and whether there was something wrong with their application or job-seeking procedures. All but three of the respondents pointed out how, even after applying for several positions, they were not asked to an interview. The women expressed their anguish at the existing system not recognizing their previous experience, rendering them jobless, and pushing them towards re-training and re-learning. Mita, a university graduate from India with experience in administrative work, expressed her despair at the situation she was in:

I have worked for five years in India and when I came here I used to apply for various administrative jobs. But so far nothing. A couple of places

37 Tania Das Gupta, "Political Economy of Gender, Race, and Class: Looking at South Asian Immigrant Women in Canada", Canadian Ethnic Studies, 26 (1994), pp. 59-73; Amina Jamal, "Situating South Asian Immigrant Women in the Canadian/Global Economy", Canadian Woman Studies, 18 (1998), pp. 26-33. 
called me for interview but never hired me. Later a friend told me that unless I do some course here on administration nobody will hire me. I need to specialize because I am an immigrant. Can you imagine? I was so shocked that all my education has gone down the drain.

Experiences such as the above-mentioned, where women were identified as lacking in Canadian work experience, reflect the "discriminatory bias" towards foreign credentials existing in Canada. ${ }^{38}$ As there is no uniform or consistent system to evaluate and assess immigrants' skills and education, the devaluation process remains largely ambiguous and hazy with no definitive answers as to why their previous education of many years are negated or underestimated. Devaluation of foreign education/work experience is also part of the systemic forms of discrimination or racism based on the assumed ethnic inferiority of certain foreign-born women and the assumed inferior quality of educational systems in their country of origin, thereby perpetuating exploitation of and disadvantage for immigrants of colour. ${ }^{39}$ South Asian women's entry into home-based businesses was therefore driven by their need to survive economically and supplement family incomes after arriving in Canada. Home-based entrepreneurship was often their last resort after multiple failed attempts at entering the mainstream labour market. Similar findings have been reported by other scholars studying immigrant women of colour and their labour market experiences in Canada. ${ }^{40}$ These scholars

have also posited that the predominant siphoning of immigrant women of colour into these unstable, low-paid, contingent job sectors elucidate how the highly racialized and gendered neoliberal, post-Fordist Canadian labour market deskills them and turns them into a captive labour force who are essential yet remain disposable in the capitalist labour market. ${ }^{41}$

38 K.D. Sadiq, "Race, Ethnicity and Immigration in the Workplace: Visible Minority Experiences and Workplace Diversity Initiatives", Canadian Issues: Immigration and the Intersections of Diversity, Spring (2005), pp. 61-66, p. 63.

39 C. Khan, "The closed door: credentialized society and immigrant experiences", Canadian Issues: Foreign Credential Recognition, Spring (2007), pp. 63-6.

40 Kiran Mirchandani, et al., "The Paradox of Training and Learning in a Culture of Contingency", in David W. Livingstone, Kiran Mirchandani and Peter Harrold. Sawchuk (eds), The Future of Lifelong Learning and Work: Critical Perspectives (Rotterdam, 2008), pp. 171-84.

Maitra, "Points of Entry", p. 130. 
Apart from institutionalized barriers, patriarchal control and gendered divisions of household work also forced many women to work from home. Many studies have pointed out how South Asian women often have to take up most of the responsibilities when it comes to child care and house work..$^{42}$ In the absence of full-time job opportunities,

such responsibilities were further exacerbated for interviewees who were forced to spend a considerable amount of time within their homes. Many women worked exceptionally long days. They usually got up early in the morning and worked throughout the day preparing meals, cleaning the house, or sending the children to school. Women who also had part-time paid work outside the home not only worked long hours, but also had to put more effort into managing their domestic responsibilities. ${ }^{43}$

Thaya, for example, mentioned to me that stitching a whole lehenga ${ }^{44}$ required at least three days of continuous sewing, and if clients wanted additional embroidery, an extra day or two. I remember visiting Thaya on a Monday afternoon, when she was extremely busy with her sewing. It was just before Diwali ${ }^{45}$ and she had to stitch fifteen lehengas for a group of girls who were to perform in a community hall. She did most of her stitching in the living room of her house (a common practice among most of my interviewees), where we sat down for the interview. As she spoke to me, I noticed how fast she was at sewing the buttons. The lehengas she had stitched were extremely intricate and artistic. She said that she had hardly slept the past week as she had several orders to handle. Often sewing while cooking or doing laundry while preparing meals for catering, women had to do a lot of juggling of tasks and felt overwhelmed at times. When women like Sheila or Priya had to cater for small parties, they not only had to deal with a large amount of cooking, but also washing and cleaning. Priya mentioned how every weekend, once she was done with making chappatis, she would be too tired to do any of her other house work. Although their husbands would pitch in sometimes, the majority of family responsibilities still rested with the women.

In the next part 1 highlight the various negotiations that women undertook to make their lives and work more meaningful in contexts where various social

42 See ibid.; Maitra, "Perspectives on Work and Family Lives".

43 Maitra, "Points of Entry", p. 13 o.

44 A type of long skirt with intricate designs.

45 A South Asian festival, often described as the Festival of Lights. People buy new clothes and exchange food, sweets and gifts with each other on this occasion. 
processes and forms of stratification impede their acceptability into mainstream Canadian society.

\section{Challenging Neoliberal Ideologies of Success}

While discussing with my respondents the various factors that motivated them to continue with their small businesses, a common response I received from the majority of the women was that stitching or cooking was more a passion or a hobby that they had never planned to practise as a form of business.

For example, a bit hesitant at first, Priya did not know what she could do from home. She had neither the money nor the experience to start a big business. It was then that her husband suggested that she could try her hand at catering. Priya knew that in her building, there were many South Asian families where both the wife and the husband went out to work, and a few of them she knew were always complaining about all the cooking and cleaning they had to do on their own. She decided to take a chance and put up a flyer in her building. She intentionally kept her charges affordable so that families would get interested. She considered herself lucky when, within a couple of days, she got a response from a member of her building who inquired if she could supply only chappatis ${ }^{46}$ for them. Priya readily agreed not only because she had got her first client, but also because generally, within her family, she had a reputation for "rolling out really soft and tasty chappatis". This was something she had learned from her mother and she was excited that her very first customer had asked her for what she was good at. Since then, as part of her business, Priya makes around 300 chapattis every weekend, and supplies them to various friends and families. Apart from that, she also delivers home-cooked food regularly to a few families. Another interviewee, Shabana, who knew stitching from before, decided to utilize this skill from home when she felt the lack of any other "proper" employment: "I love stitching. That's my passion, so I thought why not do something from home. I mean, I have friends who do that. And if I can't go out and work, what do I do? This is my work now".

There were many others like Shabana who really enjoyed sewing or cooking but had never thought of earning out of it. Shashi was a financial analyst before, and at the time of the interview she ran a catering business from her home in Brampton. While she had never dreamt of pursuing catering in Canada and had always wanted to work in her own field, unemployment forced her to start 
this business. She had learned cooking as a little girl but never had to cook while in India. It was after coming to Canada that she started cooking again and eventually took it up as a business. She had a number of clients, mostly young single men and a few families, who regularly picked up food from her on weekends. Moreover, she also cooked for small functions and get-togethers within the community, and sometimes helped a friend who ran a small sweet shop in Malton.

Since all these women had been professionals before, I was interested to understand how they perceived their transition from white-collar professionals to home-based entrepreneurs. Coming from highly educated, middle-class families, how did they view their present work from home? One of the first comments the women made was about how the unemployment they experienced after migrating to Canada led them to the decision to utilize their past "feminized" skills for economic survival. But then, there was still the fact that cooking or sewing was not something any of the women had done on a regular basis when they were in their home countries. So how did they negotiate this change in their lives? While women like Shabana, Jyoti and Priya mentioned how much they loved to cook or stitch, at the same time they also pointed out how there was a sense of despair and frustration that remained associated with the fact that they were not able to enter their own professions. Often, they would compare their previous status with their present work and family life. Priya said to me, "I often thought, oh God, look at me, I used to be in an office and now I am cooking to earn a living". It was not that the women devalued the work itself, as many of them loved to cook for their friends and family members or would do occasional sewing for themselves. What they felt depressed about was the monotony of the work along with the isolation they experienced while doing home-based work.

However, during our conversations, it was most important to note the way in which the women described their home-based work. Despite all the desperation and frustration, they had started to love and enjoy the work. Priya, for instance, pointed out to me, "Although I never had to do so much cooking before, I have started liking it now. I think one of the main reasons is the appreciation you get from people. That makes a difference".

Jyoti, who worked as a fashion designer, also referred to how much she enjoyed her work and really loved it when people praised her for the work:

In my building there are few young girls and they always come to me whenever they need new clothes to be stitched. Every time I come up with new styles and they love it. I too enjoy seeing them wear the clothes I have stitched. That's my reward. 
Appreciation from clients and family members seemed to play an important role in how women viewed their home-based work. They mentioned that their work not only gave them a sense of satisfaction when clients praised their cooking or stitching, but also instilled in them a sense of responsibility and an urge to do their work more professionally. Ghazala was one among a few women who had decided to take up garments as her profession, and at the time of the interview she was busy setting up her own store where she wanted to sell home-stitched items as well as garments brought from Pakistan. Through these efforts that the women made to initiate a business, often something they had not done before, what comes across as part of their agential self is the creativity and innovativeness they demonstrated by being able to market skills that they learned as a part of their growing up. At the same time, in their use of such a language of love, enjoyment and passion, the women actively negotiated the neoliberal ideology of "bodiless, abstract versions of knowledge and work, and models of enterprise that distance the owner-manager from the business activity". ${ }^{47}$ While not necessarily successful or productive in the neoliberal sense, the women underscored their own definition of productivity and success that remained entwined with love and enjoyment, rather than with mere financial stability. The bulk of the literature on home-based entrepreneurship that construct immigrant women's business endeavours within homes as too small, informal and unproductive fails to recognize the kind of resourcefulness at work behind such endeavours.

\section{$4 \quad$ Mobilizing Ethnic/Community Ties}

In order to set up their businesses, the women showed their "power and creativity in making and remaking their familial and kin networks". 48 These networks provided them with information about how to start a business. Although these micro-businesses were quite informal, for many there were "lots of things" they needed to know. For example, "finding clients" and "spreading the word" were two vital aspects the women needed assistance with. Sabitha spoke about the issue in detail:

I had decided to start a garment business but I had never done it before. I was worrying what to do but then there are many women from our

$\begin{array}{ll}47 & \text { Fenwick, "Transgressive Desires", p. } 711 . \\ 48 & \text { Pun, "Women Factory Workers in a Global Workspace", p. 50. }\end{array}$ 
countries who do this kind of work. I knew some of them and decided to talk to them. They were very helpful. They gave me the idea that putting up flyers will be useful. Also the grocery stores, you know, that's also my friend's idea. Three of us visited quite a few grocery stores to put up flyers. We decided to put up one flyer and then share the earning if any. ... Yes, yes we got good response. I would also let people know when I met them in the elevator. I don't mind mixing with or talking to people I don't know (laughs). A friend of mine has advertised in Bengali and Hindi newspapers, she told me yesterday. I think I'll also do that.

One of the primary ways in which women networked and built resources in order to successfully continue with their work was by creating what can be defined as "relationships" with other women within the community. Many of them also spoke about the different ways they would continue their community links. Saadiya, for instance, was a volunteer in a local community centre where she helped other less educated women prepare their résumés or type out job applications. She also shared some of her own soft-skills training with low-income and low-skilled women with the hope of assisting them to enter the labour market. Rehana offered a free English conversation course from home and gave free Quran lessons to girls. Jennifer often babysat for free if someone was facing financial difficulties. Mita gave computer lessons to South Asian women who could not afford paid training.

Elyachar, in her ethnographic study of micro-entrepreneurs in Cairo, has argued that in light of the various "conditions of structural adjustments where jobs and futures were no longer being provided by the state", the Egyptian "worker masters" would often rely on various exchanges that, although not "exchange of money", yet were "essential to the master's success in the market". ${ }^{9}$ Similar to these Egyptian workers, the South Asian immigrant women also depended on a number of practices that, by valorizing certain cultural practices, mobilized ethnic ties and kinship amongst the home workers. This valorization or reinvigoration of cultural practices was important to the women not only for "keeping and acquiring customers",50 but also effective in creating "sisterhood networks" 51 amongst themselves.

Such sisterhood networks were evident in how women often cooked and shared food to remain attached to a communal feeling. Meals occupied an

\footnotetext{
49 Julia Elyachar, Markets of Dispossession: NGOs' Economic Development, and the State in Cairo (Durham, NC, 2005), pp. 26, 42.

50 Ibid., p. 140.

$51 \quad$ Pun, "Women Factory Workers in a Global Workspace", p. 61.
} 
important place in the lives of the South Asian women. When I visited them for interviews, I was often offered snacks and sweets, and many of them would ask me to stay for lunch or dinner. The few times that I did stay, the meals were lavish, consisting of meat dishes, kebabs, pulav, biryani, daal, chappatis, vegetables, and kheer or gulab jamun. Sharing meals and cooking was a way for women to maintain their ties with each other. These get-togethers over food not only forged friendships, but also provided opportunities to share information, exchange social skills and break out of isolation. The culinary activities thus functioned as a "technique of nearness",52 a form of sociability and a collective, as opposed to individualistic, competitive neoliberal work processes. The women also wore similar ethnic clothing within their homes or when going out for grocery shopping, spoke in their vernacular, and spent time together in long sessions of adda-"long, informal, and unrigorous conversations" that formed a vital idiom of social interaction among them. ${ }^{53}$ Apart "from fostering a semblance of community life, these informal networks of communication that women establish with each other, therefore, also become vital nodal points for exchanging possibilities of finding work and economically productive activities". ${ }^{4}$

\section{5}

\section{Conclusions}

In this chapter, I have highlighted how South Asian immigrant women, despite adopting home-based entrepreneurship that is considered as one of the most effective means by which immigrants can avoid labour market constraints and create opportunities for themselves, challenge the ideologies of productivity and success that remain associated with the notion of entrepreneurial self. While, within a neoliberal economy, success and productivity are measured in terms of economics, these women through their work provide an alternative. By underscoring love, community ties and familial relations, they highlight how the creation of relationships, love and mutual support can also be markers of entrepreneurial success. Despite being located in an individualized, competitive and racialized market economy, these women, rather than pursuing the ideas of a neoliberal worker-subject, redefined the notion of enterprising

\footnotetext{
52 Keya Ganguly, States of Exception: Everyday Life and Postcolonial identity (Minneapolis, 2001), p. 136.

53 Dipesh Chakrabarty, "Adda, Calcutta: Dwelling in Modernity”, Public Culture, 11 (1999), pp. 109-45, p. 110.

54 Maitra, "Perspectives on Work and Family Lives", p. 16o.
} 
selves to encompass collaboration, love and creativity. These are women whose endeavours not only need to be recognized, but also their businesses counted as an important part of the Canadian economy.

Going beyond the discourse of any static definition of productivity or selfsufficiency, these efforts on the part of the women are important in delineating how immigrant women of colour can actively refashion their own course to "success", "taking a multiple front, criss-crossing individual and collective levels, and negotiating not only with" racial and gendered factors but cultural experiences as well. ${ }^{55}$ In recognizing their tremendous, effort-filled abilities to sustain and survive in Canada, I conclude this chapter with a quotation from one of my interviewees, Sheila, who aptly sums up the significance of their work for the Canadian society and its labour market:

Because we do not have big businesses we are not taken seriously. But there are so many women doing this, and they want to expand and be taken seriously. I mean, even for me my earning is important for my family. ... I am doing important work, and it takes a lot of my time, energy and resource. I want the society to recognize that. Do not look down upon me just because I am South Asian.

Unless we acknowledge that creativity, originality and passion play an important role in the business efforts of these women, we will lose sight of the agency that remains embedded within their initiatives to determine an opportunity for themselves within the precariousness and uncertainty they experience in their everyday lives in Canada.

55 Pun, "Women Factory Workers in a Global Workspace", p. 196. 